\title{
High Mobility Group Box 1 and Heat Shock Protein-70 Expression Post (-)-Epigallocatechin-3-Gallate in East Java Green Tea Methanolic Extract Administration During Orthodontic Tooth Movement in Wistar Rats
}

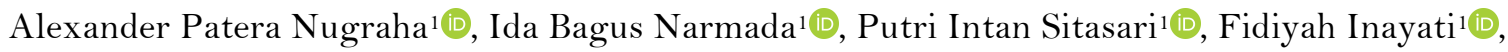 \\ Rahendra Wira ${ }^{\circledR}$, Ari Triwardhani ${ }^{1}$, Thalca Hamid ${ }^{1}$, I I Gusti Aju Wahju Ardani1 ${ }^{\circledR}$, Irwadi

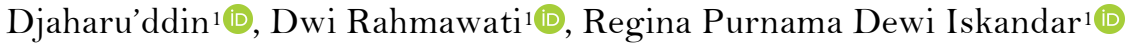

${ }^{1}$ Orthodontics Department, Faculty of Dental Medicine, Airlangga University, Surabaya, Indonesia.

Author to whom correspondence should be addressed: Regina Purnama Dewi Iskandar, Orthodontics Department, Faculty of Dental Medicine, Airlangga University, Surabaya, Indonesia. 60132. Phone: +62 315030255. E-mail: regina-p-di@ffkg.unair.ac.id.

Academic Editors: Alessandro Leite Cavalcanti and Wilton Wilney Nascimento Padilha

Received: 22 October 2019 / Accepted: 10 February 2020 / Published: 26 February 2020

\begin{abstract}
How to cite this article: Nugraha AP, Narmada IB, Sitasari PI, Inayati F, Wira R, Triwardhani A, et al. High mobility group box 1 and heat shock protein-70 expression post (-)-epigallocatechin-3-gallate in East Java green tea methanolic extract administration during orthodontic tooth movement in wistar rats. Pesqui Bras Odontopediatria Clín Integr. 2020; 20:e5347. https://doi.org/10.1590/pboci.2020.040
\end{abstract}

\begin{abstract}
Objective: To investigate the expression of High Mobility Group Box 1 (HMGB1) and Heat Shock Protein-70 (HSP-70) during orthodontic tooth movement (OTM) after (-)- Epigallocatechin-3-Gallate (EGCG) in East Java Green Tea (Camelia Sinensis) Methanolic Extract (GTME) administration in vivo. Material and Methods: 28 Wistar rats (Rattus Novergicus) was used and divided into 4 groups accordingly: K- without EGCG and OTM; K+ with OTM, without EGCG for 14 days; T1 with OTM for 14 days and EGCG for 7 days; treatment group 2 (T2) with OTM and EGCG for 14 days. OTM animal model was achieved through the installation of the OTM device by means of NiTi close coil spring with $10 \mathrm{~g}$ force placed between the first incisor and first maxillary molars. The samples were terminated on Day 14. The pre-maxillary was isolated for the immunohistochemical examination. Analysis of Variance (ANOVA) then continued with Tukey Honest Significant Difference (HSD) $(\mathrm{p}<0.05)$ was performed to analyze the data. Results: The highest HMGB1 and HSP-70 expression were found in the $\mathrm{K}+$ group pressure side, meanwhile the lowest HMGB1 and HSP-70 expression were found in K- group tension side in the alveolar bone. There was a significant decrease of HMGB1 and HSP-70 expression in T2 compared to T1 and K+ with significant between groups $(\mathrm{p}<0.05 ; \mathrm{p}=0.0001)$. Conclusion: The decreased expression of HMGB1 and HSP-70 in alveolar bone of OTM wistar rats due to post administration of GTME that consisted EGCG.
\end{abstract}

Keywords: Orthodontics; Tooth Movement Techniques; HMGB1 Protein; Antioxidants. 


\section{Introduction}

In the modern economic era, tea is an important economic commodity and it has abundant benefits for the human being. In countries like China, United Kingdom, Japan and Indonesia, drinking tea has become a culture. The number of tea consumption and production increase annually in the world. Tea production has been increased from 3.152.987 in 2003 to 3.233.216 tons in 2004, while consumption from 1.344.200 in 2003 to 1.414.400 tons in 2004. The largest tea producer in the world is India, China, Sri Lanka, Kenya and Indonesia, with about $65 \%$ export of tea products. Indonesia is a tropical country with a good climate for tea plant to grow. One of tea field in Indonesia located in Perusahaan Perkebunan Nusantara XII, Wonosari, Lawang, Malang, East Java, Indonesia [1].

After water, tea is the most favorite drink in the world [2]. Tea consumption not only evolved in China but also in Indonesia, from nutrition to medicine to meditation aid to a drink of leisure and culture. The source of all true tea is Camellia Sinensis. Tea has various, unique, and distinguishes from all others plants such as phenol, flavonols, amino acids, chlorophyll, carbohydrates and etc. The most important compound consisted in tea is catechins. The catechins occupy $60-80 \%$ of the total number of polyphenols; thus, that are responsible for maintaining good health. Catechins could be found in the other plant, but the quantity of the number is very small. There are variations in the contents of the tea flush dependent on soil, climate and general growth conditions [3]. It believed that East Java Green Tea has an abundant amount of catechins.

Kuntze has made the classification for C. sinensis (L.) based on the processing used into four different subtypes: green tea, black tea, white tea and oolong tea. Green tea is produced without fermentation and thus, oxidation of the polyphenolic components is prevented. Green tea as an infusion has been extensively consumed as a beverage in Asian countries for centuries. Green tea and its extracts are rich in polyphenolic compounds, most of which are flavanols, commonly known as catechins. The primary catechins in green tea are (-)-epicatechin (EC), (-)-epicatechin-3-gallate (ECG), (-)-epigallocatechin (EGC) and (-)-epigallocatechin-3gallate (EGCG). Furthermore, (+)-catechin (C), (+)-gallocatechin (GC), (-)-gallocatechin-3-gallate (GCG) and (+)-catechin-3-gallate $(\mathrm{CG})$ [4]. Green tea has more catechins than other tea variants. Based on in vitro and in vivo study, Catechin has strong antioxidants [5]. Green tea has been known to have many benefits for human life, including being an immunomodulator and antifungal, ameliorate bone resorption, and promote bone formation [6-9].

Nowadays, cosmetic and facial aesthetics was considered an important aspect of human being. Good facial profile and aesthetic could be achieved through Orthodontic treatment. Orthodontic treatment is the treatment that aligns the teeth to obtain occlusion function and facial aesthetics. Orthodontic Tooth Movement (OTM) is a part of orthodontic treatment that could move the teeth within the alveolar bone by means of orthodontic force. OTM could induce and stimulate various biochemical, cytokine, chemokine, and cellular activity in the periodontal tissue that allowing tooth movement [10,11].

Previous study mentioned that High Mobility Group Box Protein 1 (HMGB1) originating from periodontal ligament (PDL) cells could be a potential regulator in the process of orthodontic tooth movement and periodontal tissue remodeling [12]. Cultured PDL fibroblasts produced HMGB1 when putting under mechanical stress. HMGB1 was induced in the PDL during OTM. HMGB1 initiated macrophage migration and osteoclastogenesis. HMGB1 induced cell proliferation and osteoblastic differentiation of PDL cells. HMGB1 works as an accessory regulator of bone metabolism during OTM [13].

OTM could trigger cytotoxic stress due to the mechanical force load that stimulates major protein expressed in periodontal tissue such as heat shock proteins (HSPs). PDL has a dynamic role as a shock 
absorber during OTM. HSP expression in the periodontal tissue is very limited. In addition, it has been mentioned that in vitro experiment, microarray revealed that only HSP70 increased when human PDL fibroblasts were exposed to mechanical stress [14,15].

Green tea consumption has become a daily lifestyle [3]. Patients with orthodontic treatment have the possibility of consuming green tea as a daily beverage. EGCG that consisted of green tea can act as a potential antioxidant activity that affects the HMGB1 and HSP-70. Until now, there is no study about the effect antioxidant activity of EGCG during OTM on HMGB1 and HSP-70. Thus, this study aim was to investigate the expression of HMGB1 and HSP-70 during OTM in Wistar rats (Rattus Novergicus) after EGCG in East Java Green Tea Methanolic Extract (GTME) administration.

\section{Material and Methods}

Study Design

The laboratory experimental study with a post-test only control group design was carried out.

Product Preparation

Grean tea leaf (C. Sinensis) was obtained from Perkebunan Nusantara XII Company, Wonosari, Lawang, Malang, East Jawa Indonesia. The preparation of C. Sinensis extract and EGCG isolation were done at the Faculty of Pharmaceutical Science, Widya Mandala Catholic University, Surabaya, Indonesia. 2.5 grams of dried C. Sinensis leaf was boiled in $200 \mathrm{~mL}$ distilled water for $30 \mathrm{~min}$. The maceration method was done to obtain Green Tea Methanolic Extract (GTME). The C. Sinensis extract was freeze-dried to maintain the active compound. Thus, C. Sinensis extract was filtered. The isolation of EGCG from C. Sinensis extract was done by Thin Layer Chromatography (TLC) method then compared with (-)-Epigallocatechin Gallate Hydrate (Cat no. E0694, Tokyo Chemical Co., Ltd., Japan) for verification [8]. The identification of phenolic compounds was done using an HPLC system (Ag-ilent 1260, Agilent Technologies Deutschland GmbH, Waldbronn, German) consisting of a vacuum degasser, an autosampler, and a binary pump with a maximum pressure of 400 bar.

Sampling

The simple blind random sampling was done. Thus, the sample size was determined by using Lameshow's minimum sample size formula.

The sample consisted of healthy twenty-eight Wistar rats (Rattus Novergicus), aged around 16-20 weeks-old with the weights between $200-250 \mathrm{~g}$, selected blind-randomly into control and treatment groups, which were then divided into 4 groups (Figure 1A). OTM was installed by using NiTi close coil spring with 6 mm length (American Orthodontics Corp., Sheboygan, WI, USA), placed between the incisor and maxillary molars to move the molar mesially with $10 \mathrm{~g}$ force and measured by the using tension gauge (American Orthodontics Corp., Sheboygan, WI, USA). The fixed orthodontic appliance was fixated by applying 0.07 stainless steel ligature wire (American Orthodontics Corp., Sheboygan, WI, USA) (Figure 1B) [9].

Next, the administration of EGCG in GTME was done per orally by utilizing oral gavage, a stomach tube with a dose of $300 \mathrm{mg} / 1000 \mathrm{~g}$ bodyweight every day. All samples were sacrificed after 14 days by rodent anesthesia (60 mg / bodyweight of ketamine and $3 \mathrm{mg} /$ bodyweight of xylazine) (Sigma Aldrich, Merck KGaA, Darmstadt, Germany). Rat's premaxillae were dissected and placed in 10\% formalin (OneMed, Surabaya, Indonesia) for four days then premaxillae were decalcified for 1 month by using ethylenediaminetetraacetic acid (EDTA) (OneMed, Surabaya, Indonesia). Thus, the sample was undergoing tissue processing according to the previous method [10]. 
Immunohistochemical (IHC) staining using a 3.3'-diaminobenzidine stain kit (DAB) (Sigma Aldrich, Merck KGaA, Darmstadt, Germany) with the counterstaining using Hematoxylin Eosin (Sigma Aldrich, Merck KGaA, Darmstadt, Germany) was performed. Anti-HMGB1 (no.cat sc-56698) and anti-HSP-70 (no cat. Sc-24) (Santa Cruz Biotechnology Inc., Dallas, TX, USA) antibody monoclonal (AbMo) were used. The observation and examination of expression numbers from HMGB1 and HSP-70 in the alveolar bone were carried out by 2 observers in 5 different visual fields by applying Nikon H6ooL light microscope (Nikon Corp., Tokyo, Japan) at 1000x magnification (Nikon Corp., Tokyo, Japan).
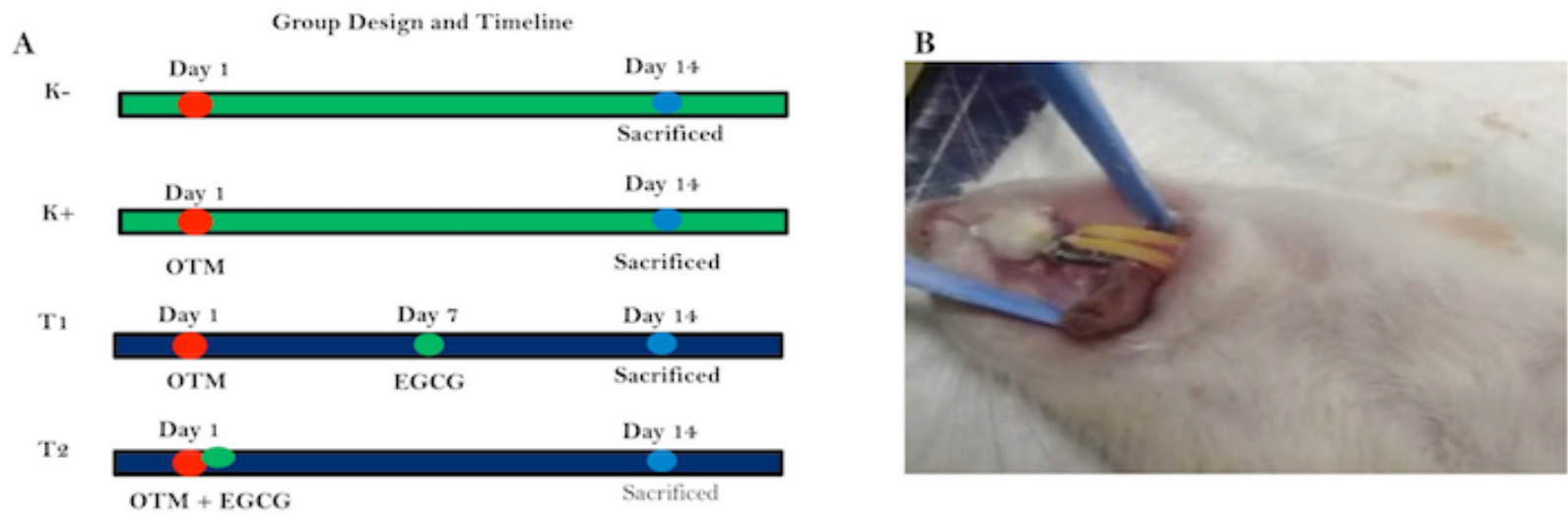

Figure 1. A: Study group design and timeline; B: OTM animal model.

Data Analysis

The data were analyzed by Statistical Package for the Social Sciences 20.0 software (SPSS for Windows, Chicago, USA). Descriptive statistics were given using \pm Standard Deviation (SD). One-way Analysis of Variance (ANOVA) and Tukey Honest Significant Difference (HSD) (p<0.05) were implemented based on Shapiro-Wilk and Levene's test ( $\mathrm{p}>0.05)$.

Ethical Aspects

This study obtains an ethical clearance approval (Protocol No. 074/HRECC.FODM/III/2019) from the Ethics Research Committee of Faculty of Dental Medicine, Universitas Airlangga Surabaya, East Java, Indonesia

\section{Results}

The $4.37 \%$ of EGCG concentration was detected by HPLC in the green tea methanolic extract by means of maceration method. All data were homogenous and normally distributed ( $\mathrm{p}>0.05)$. The result of IHC examination of HMGB1 expression can be seen in Figure 2 A-B; meanwhile, HSP-70 expression can be seen in Figure 3 A-B. K+ groups show more positive expression (brown colored) compared to the other groups. The highest HMGB1 expression was found in the $\mathrm{K}+$ group's pressure side, meanwhile the lowest HMGB1 expression was found in K- group's tension side. There was a significant decrease of HMGB1 expression between groups $(\mathrm{p}=0.0001)$ (Figure $2 \mathrm{C}-\mathrm{D})$. The highest HSP-70 expression was found in the K+ group's pressure side, meanwhile the lowest HSP-70 expression was found in the K-group's tension side. There was a significant decrease in HSP-70 expression between groups ( $\mathrm{p}=0.0001)$ (Figure $3 \mathrm{C}-\mathrm{D})$. The results showed that there was a significant decrease of HSP-70 and HMGB1 expression in T2 group compared to T1 and K+ groups in both pressure and tension side. 

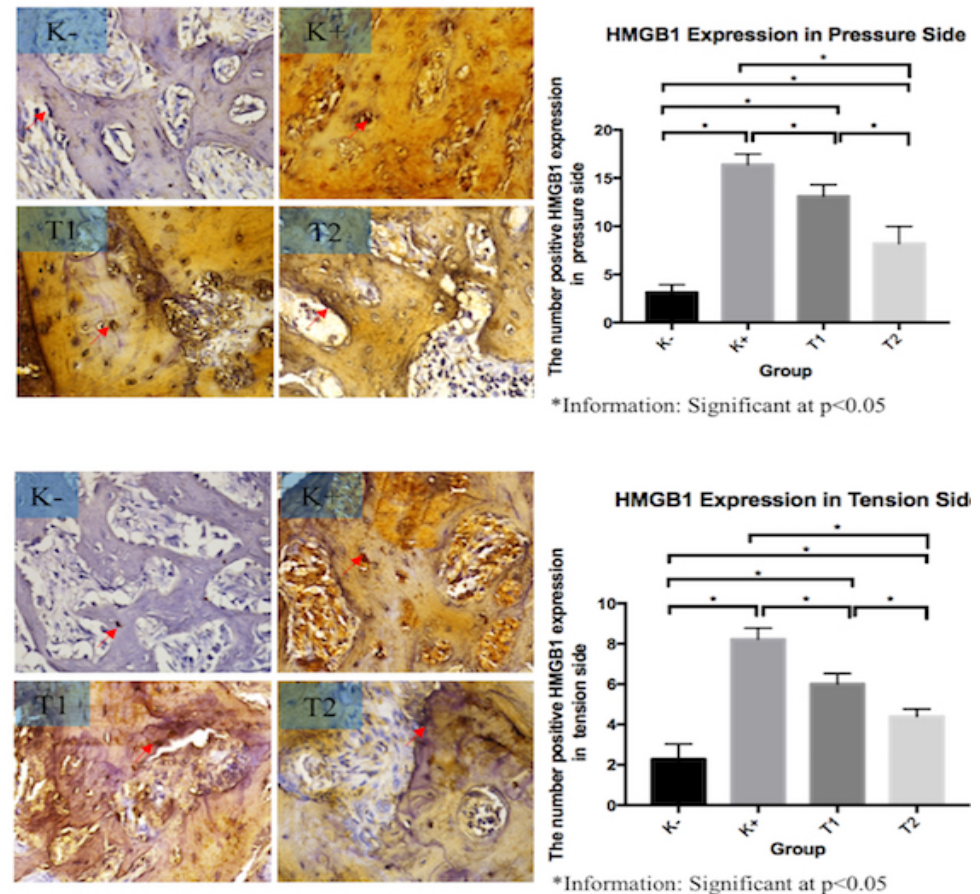

Figure 2. The comparison of IHC result shows a HMGB1 positive expression in the alveolar bone of Wistar rats (R. Novergicus) during OTM with 1000x magnification by light microscope. (A) The red arrow pointed the positive expression of HMGB 1 in pressure area in each group. (B) The red arrow pointed the positive expression of HMGB 1 in tension area in each group. (C) Represent the positive number of HMGB1 expression in pressure area between groups (D) Represent the positive number of HMGB1 expression in tension area between groups. Data are expressed as mean \pm SD $(n=7)$, significant at $\mathbf{p}<0.05$. K-: negative control group without OTM and without GTME administration; $K+$ : positive control group with OTM and PBS administration for 14 days; T1: group with OTM for 14 days and GTME administration from day 7 to day 14; T2: OTM with GTME administration for 14 days.
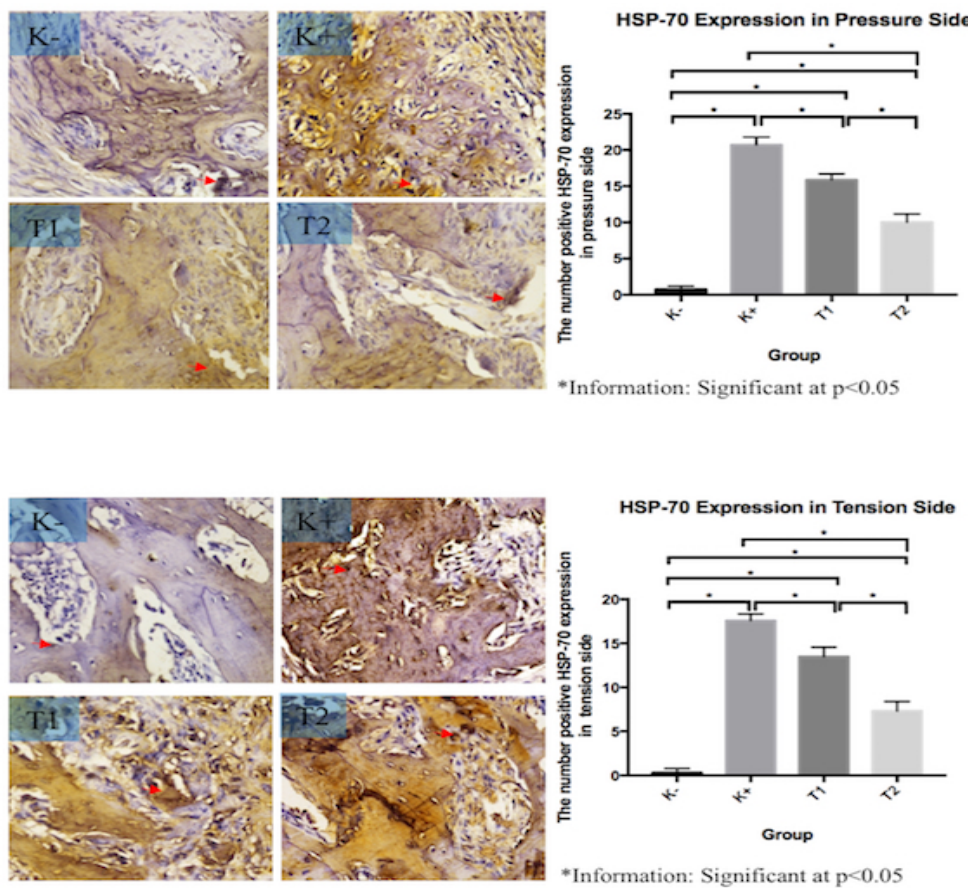

HSP-70 Expression in Tension Side

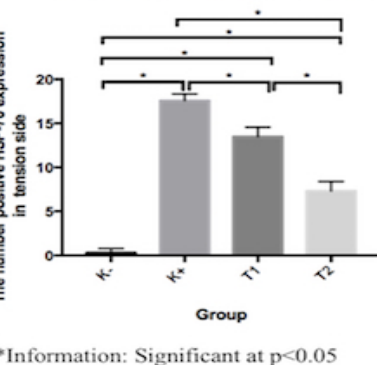

Figure 3. The comparison of IHC result shows a HSP-70 positive expression in the alveolar bone of Wistar rats (R. Novergicus) during OTM with 1000x magnification by light microscope. (A) The red arrow pointed the positive expression of HSP-70 in pressure area in each group. (B) The red arrow pointed the positive expression of HSP-70 in tension area in each group. (C) Represent the positive number of HSP-70 expression in pressure area between groups (D) Represent the positive number of HSP-70 expression in tension area between groups. Data are expressed as mean \pm SD $(n=7)$, significant at $p<0.05$. K-: negative control group without OTM and without GTME administration; $\mathrm{K}+$ : positive control group with OTM and PBS administration for 14 days; T1: group with OTM for 14 days and GTME administration from day 7 to day 14; T2: OTM with GTME administration for 14 days. 


\section{Discussion}

The orthodontic force that applied in this as much as $10 \mathrm{~g}$ of a light force to induce OTM without Tooth Root Resorption (TRR) for 14 days in rats. Histopathological examination in the tissue changes due to OTM was observed in periodontal tissue in the pressure and tension sides. This study found that HMGB1 expression increase greatly in $\mathrm{K}+$ group. HMGB1 plays an important role as an inflammatory cytokine released from necrotic cells or secreted from macrophages or monocytes, which receive stress signals [13]. Increased expression of HMGB1 will induce the activation of Nuclear Factor Kappa Beta (NFKB) and it will significantly secrete pro-inflammatory cytokines such as Tumor Necrosis Factor-alpha (TNF-a), Interleukin 1alpha (IL-1a), IL-b, IL-6, IL-8 and many others. In the initial stage of OTM, cells stressed and necrosis, which is related to the activation of inflammatory cells, the appearance of hyalinized necrotic tissue in the PDL $[16,17]$. It indicated that HMGB1 is involved in the reaction of the cells in the PDL. The higher expression of HMGB1 found in PDL during OTM. A previous study mentions that pressure or mechanical stress will sensitize the migration of macrophage through an increase of HMGB1 expression in vitro. Mechanical stress or pressure-induced osteoclast differentiation and osteoclastogenesis through up-regulation of HMGB1 expression in vitro [18-20]. HMGB1 has a pivotal role as an accessory regulator of alveolar bone remodeling in periodontal tissue during OTM [13].

There was a significant decrease in HMGB1 expression in the T2 group compared to T1 and $\mathrm{K}+$ groups in this study. (-)-Epigallocatechin-3-gallate (EGCG) is an active component of green tea with abundant advantages for health such as inflammation and oxidative stress associated disease [21-23]. Previous study has shown that anti-inflammation contained in EGCG can inhibit endotoxin-induced HMGB1 [24]. Orthodontic force induces HMGB1 expression in PDL cells [13]. Excessive expression of HMGB1 is undesirable because it will induce excessive pro-inflammatory cytokine resulted in excessive bone resorption during OTM [13,25]. Administration of EGCG during OTM can inhibit excessive expression of HGMB1 because of it's antioxidant and anti-inflammatory ability [21,26]. Thus, EGCG could stimulate bone remodeling [8,9].

Recent study result shows that the highest HSP-70 expression was found in the $\mathrm{K}+$ group's pressure side, meanwhile the lowest HSP-70 expression was found in the K- group's tension side. During mechanical load or stress of OTM, Major proteins were expressed in many tissues and organs is transiently expressed are known as heat shock proteins (HSPs). HSPs or stress proteins are induced in various cells by specific types of stress. HSPs play pivotal roles in various conditions both in physiological or pathological cellular response [27]. This study result in line with previous research, which demonstrated that the expression of HSP70 expressed in the late phase after OTM [28]. The expression of HSP70 may function in a homeostatic mechanism to compensate for PDL cell changes occurring during orthodontic force [29]. The result of this study showed that there was a significant decrease of HSP-70 expression in T2 group compared to T1 and K+ groups. Previous study stated that EGCG specifically reduced the expression of HSP70 and HSP90 without affecting the levels of other HSPs [30]. During OTM, excessive expression of HSP-70 can occur depends on the force that applied. The OTM force can cause oxidative stress in PDL, which activated Heat Shock Factor-1 that can lead to HSP-70 increase in the cytoplasm. This increase resulted in the excretion of HSP-70 from cell [28,30]. Meanwhile, EGCG suppressed the over-expression of HSP 70 [31,32]. This result supported our previous study that found post GTME could enhance RUNX2 and OSX in alveolar bone of Wistar Rats during OTM due to presence of EGCG in the extract [33]. The antioxidant ability of EGCG that consisted in GTME may increase the bone turnover [8,9,13]. 


\section{Conclusion}

The EGCG presence in the East Java green tea methanolic extract could decrease HSP-70 and HMGB1 expression in the alveolar bone of Wistar Rats compared to that without the extract based on its molecular aspect.

\section{Authors' Contributions}

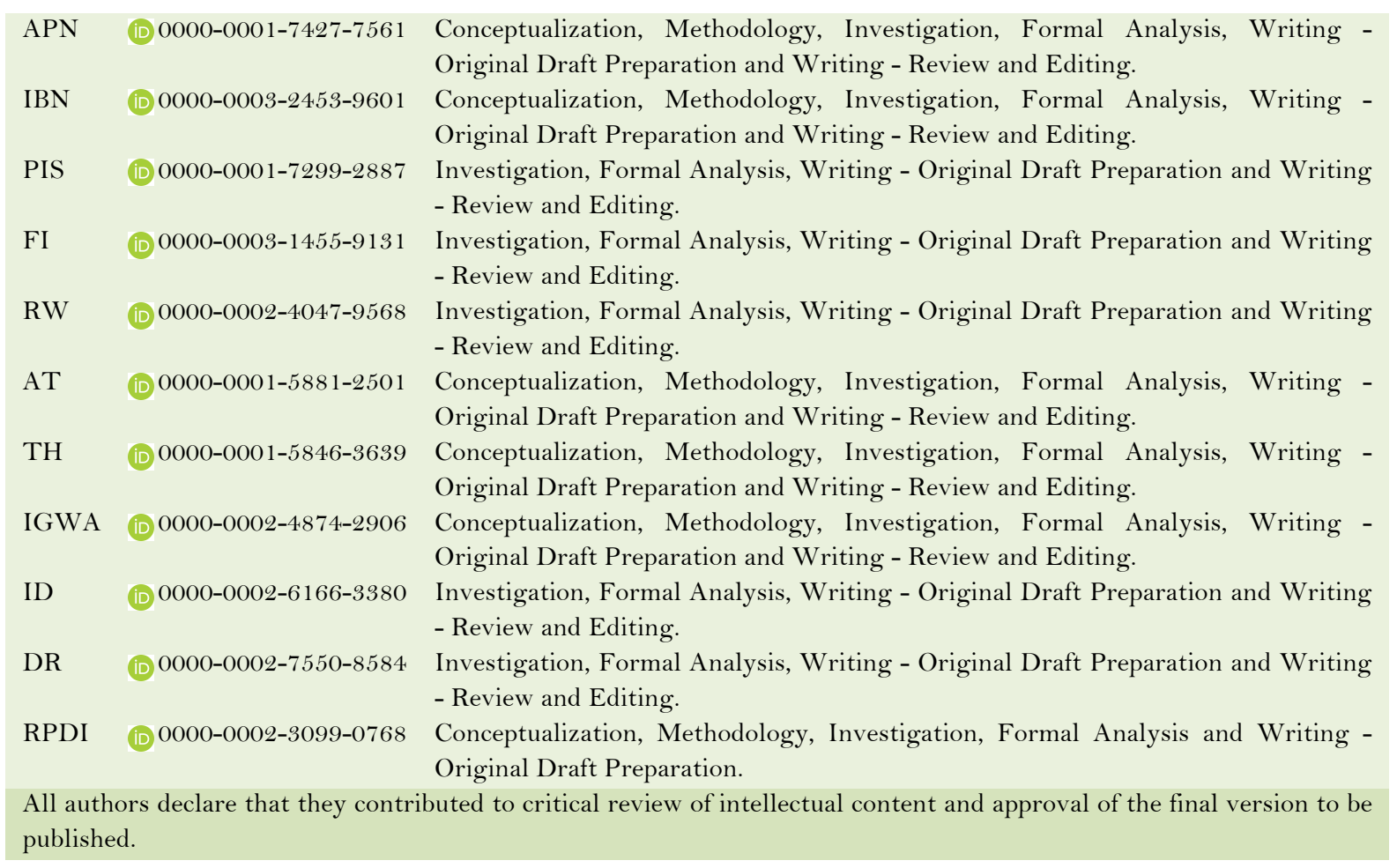

\section{Financial Support}

This study was funded by Penelitian Dosen Pemula (PDP) Airlangga University, Surabaya, Indonesia with appointment number $2111 / \mathrm{UN} 3.1 .2 / \mathrm{LT} / 2019$.

\section{Conflict of Interest}

The author disclose of any conflict of interest.

\section{Acknowledgement}

The Authors would like to thank Animal Laboratory, Stem Cell Research and Development Center, Airlangga University for the support.

\section{References}

[1] Kustanti VR, Widiyanti T. Research on Supply Chain in the Tea Sector in Indonesia. The Business Watch Indonesia 2007; 58pp.

[2] Prasetyo RA, Nasronudin, Rahayu RP. The effect of (-)-epigallocatechin-3-gallate green tea on neutrophil count and infected cells by candida albicans in a murine model of oral candidiasis. World J Pharm Pharm Sci 2015; 4(6):89-99.

[3] Bisgaard SMC. Future of tea and tea culture. Ritsumeikan Research Repository. Available from: http://www.ritsumei.ac.jp/acd/re/ssrc/result/memoirs/tokusyuugou201707/tokusyuugou201707-09.pdf. [Accessed on Aug 22, 2019].

[4] Aggett P, Aguilar F, Crebelli R, Dusemund B, Filipič M, Frutos MJ, et al. Scientific opinion on the safety of green tea catechins. EFSA Journal 2018; 16(4):e05239. https://doi.org/10.2903/j.efsa.2018.5239 
[5] Soni RP, Katoch M, Kumar A, Ladohiya R, Verma P. Tea: production, composition, consumption and its potential an antioxidant and antimicrobial agent. Intl J Food Ferment Technol 2015; 5(2):95-106.

[6] Rahayu RP, Prasetyo RA, Purwanto DA, Kresnoadi U, Iskandar RPD, Rubianto M. The immunomodulatory effect of green tea (Camellia sinensis) leaves extract on immunocompromised Wistar rats infected by Candida albicans. Vet World 2018;11(6):765-70. https://doi.org/10.14202/vetworld.2018.765-770

[7] Shen CL, Yeh JK, Cao JJ, Chyu MC, Wang JS. Green tea and bone health: Evidence from laboratory studies. Pharmacol Res 2011; 64(2):155-61. https://doi.org/10.1016/j.phrs.2011.03.012

[8] Shen CL, Han J, Wang S, Chung E, Chyu MC, Cao JJ. Green tea supplementation benefits body composition and improves bone properties in obese female rats fed with high-fat diet and caloric restricted diet. Nutr Res 2015; 35(12):1095-105. https://doi.org/10.1016/j.nutres.2015.09.014

[9] Shen CL, Smith BJ, Li J, Cao JJ, Song X, Newhardt MF, et al. Effect of long-term green tea polyphenol supplementation on bone architecture, turnover, and mechanical properties in middle-aged ovariectomized rats. Calcif Tissue Int 2019; 104(3):285-300. https://doi.org/10.1007/s00223-018-0489-y

[10] Narmada IB, Husodo KRD, Ardani IGA, Rahmawati D, Nugraha AP, Iskandar RPD. Effect of vitamin d during orthodontic tooth movement on receptor activator of nuclear factor kappa-B ligand expression and osteoclast number in pregnant Wistar rat (Rattus novergicus). J Krishna Instit Med Sci Univ 2019; 8(1):37-42.

[11] Krishnan V, Davidovitch Z. Cellular, molecular, and tissue-level reactions to orthodontic force. Am J Orthod Dentofac Orthop 2006; 129(4):469.e1-32. https://doi.org/10.1016/j.ajodo.2005.10.007

[12] Lv S, Li J, Feng W, Liu H, Du J, Sun J, et al. Expression of HMGB1 in the periodontal tissue subjected to orthodontic force application by Waldo's method in mice. J Mol Histol 2015; 46(1):107-14.

https://doi.org/10.1007/s10735-014-9606-Z

[13] Kanzaki H, Nakamura Y. Orthodontic tooth movement and HMGB1. J Oral Biosci 2018; 60(2):49-53. https://doi.org/10.1016/j.job.2018.03.002

[14] Muraoka R, Nakano K, Kurihara S, Yamada K, Kawakami T. Immunohistochemical expression of heat shock proteins in the mouse periodontal tissues due to orthodontic mechanical stress. Eur J Med Res 2010; 15(11):475-82. https://doi.org/10.1186/2047-783X-15-11-475

[15] Araujo RMS, Oba Y, Moriyama K. Identification of genes related to mechanical stress in human periodontal ligament cells using microarray analysis. J Periodont Res 2007; 42(1):15-22. https://doi.org/10.1111/j.1600-0765.2006.00906.x

[16] Andersson U, Wang H, Palmblad K, Aveberger AC, Bloom O, Erlandsson-Harris H, et al. High mobility group 1 protein (HMG-1) stimulates proinflammatory cytokine synthesis in human monocytes. J Exp Med 2000; 192(4):56570. https://doi.org/10.1084/jem.192.4.565

[17] Park JS, Arcaroli J, Yum HK, Yang H, Wang H, Yang KY, et al. Activation of gene expression in human neutrophils by high mobility group box 1 protein. Am J Physiol Cell Physiol 2003; 284(4):C870-C879. https://doi.org/10.1152/ajpcell.00322.2002

[18] Wolf M, Lossdörfer S, Abuduwali N, Jäger A. Potential role of high mobility group box protein 1 and intermittent PTH (1-34) in periodontal tissue repair following orthodontic tooth movement in rats. Clin Oral Investig 2013; 17(3):989-97. https://doi.org/10.1007/s00784-012-0777-2

[19] Wolf M, Lossdörfer S, Küpper K, Jäger A. Regulation of high mobility group box protein 1 expression following mechanical loading by orthodontic forces in vitro and in vivo. Eur J Orthod 2014; 36(4):624-31. https://doi.org/10.1093/ejo/cjto37

[20] Wolf M, Lossdörfer S, Craveiro R, Götz W, Jäger A. Regulation of macrophage migration and activity by highmobility group box 1 protein released from periodontal ligament cells during orthodontically induced periodontal repair: an in vitro and in vivo experimental study. J Orofac Orthop 2013; 74(5):420-34. https://doi.org/10.1007/s00056-013-0167-7

[21] Meng XY, Li B, Liu S, Kang H, Zhao L, Zhou R. EGCG in green tea induces aggregation of HMGB1 protein through large conformational changes with polarized charge redistribution. Sci Rep 2016; 6:22128. https://doi.org/10.1038/srep22128

[22] Frei B, Higdon JV. Antioxidant activity of tea polyphenols in vivo: evidence from animal studies. J Nutr 2003; 133(10):3275S-84S. https://doi.org/10.1093/jn/133.10.3275S

[23] Riegsecker S, Wiczynski D, Kaplan MJ, Ahmed S. Potential benefits of green tea polyphenol EGCG in the prevention and treatment of vascular inflammation in rheumatoid arthritis. Life Sci 2013; 93(8):307-12. https://doi.org/10.1016/j.lfs.2013.07.006

[24] Li W, Ashok M, Li J, Yang H, Sama AE, Wang H. A major ingredient of green tea rescues mice from lethal sepsis partly by inhibiting HMGB1. PLoS One 2007; 2(11):e1153. https://doi.org/10.1371/journal.pone.0001153

[25] Yoshihara-Hirata C, Yamashiro K, Yamamoto T, Aoyagi H, Ideguchi H, Kawamura M, et al. Anti-HMGB1 neutralizing antibody attenuates periodontal inflammation and bone resorption in a murine periodontitis model. Infect Immun 2018; 86(5):e00111-18. https://doi.org/10.1128/IAI.00111-18 
[26] Li W, Zhu S, Li J, Assa A, Jundoria A, Xu J, et al. EGCG stimulates autophagy and reduces cytoplasmic HMGB1 levels in endotoxin-stimulated macrophages. Biochem Pharmacol 2011; 81(9):1152-63. https://doi.org/10.1016/j.bcp.2011.02.015

[27] Muraoka R, Nakano K, Kurihara S, Yamada K, Kawakami T. Immunohistochemical expression of heat shock proteins in the mouse periodontal tissues due to orthodontic mechanical stress. Eur J Med Res 2010; 15(11):475-82. https://doi.org/10.1186/2047-783x-15-11-475

[28] Kaneko-Tanaka K, Kurokawa A, Mitsuhashi M, Fujita S, Goseki T, Yamaguchi M, et al. Expression of heat shock protein 70 in the periodontal ligament during orthodontic tooth movement. Int J Oral Med Sci 2010; 9(2):115-21.

[29] Muraoka R, Nakano K, Matsuda H, Tomoda M, Okafuji N, Yamada K, et al. A consideration on the role of HSP70 appearing in the periodontal tissues due to experimental orthodontic force. J Hard Tiss Biol 2011; 20(4):275-82. https://doi.org/10.2485/jhtb.20.275

[30] Tran PL, Kim SA, Choi HS, Yoon JH, Ahn SG. Epigallocatechin-3-gallate suppresses the expression of HSP7O and HSP9O and exhibits anti-tumor activity in vitro and in vivo. BMC Cancer 2010; 10:276. https://doi.org/10.1186/1471-2407-10-276

[31] Westerheide SD, Morimoto RI. Heat shock response modulators as therapeutic tools for diseases of protein conformation. J Biol Chem 2005; 280(39):33097-100. https://doi.org/10.1074/jbc.R500010200

[32] Tang XY, Zhu YQ. Epigallocatechin-3-gallate suppressed the over-expression of HSP 70 and MDR1 induced by heat shock in SGC 7901. J Chemother 2008; 20(3):355-60. https://doi.org/10.1179/joc.2008.20.3.355

[33] Sitasari PI, Narmada IB, Hamid T, Triwardhani A, Nugraha AP, Rahmawati D. East Java green tea methanolic extract can enhance RUNX2 and Osterix expression during orthodontic tooth movement in vivo. J Pharm Pharmacogn Res 2020; 8(4):290-8. 